\title{
Pengaruh Jenis dan Konsentrasi Pemlastis terhadap Karakteristik Komposit Bioplastik Pati Ubi Talas Belitung (Xanthosoma sagittifolium) - Kitosan
}

The Effect of Types and Concentrations of Plasticizer Materials on Against the Characteristics of Belitung Taro Potato Starch Bioplastic Composite (Xanthosoma sagittifolium) - Chitosan.

\section{Runa Ramadanty Aisyi Putri, Amna Hartiati*, Bambang Admadi Harsojuwono}

PS Teknologi Industri Pertanian, Fakultas Teknologi Pertanian, Universitas Udayana, Kampus Bukit Jimbaran, Badung, Kode pos : 80361; Telp/Fax : (0361) 701801

Diterima 02 Agustus 2021 / Disetujui 19 Agustus 2021

\begin{abstract}
This study aims to determine the effect of the type and concentration of plasticizers and their interactions on the characteristics of the taro potato starch bio-plastic composite and to determine the type and concentration of the plasticizer that produces the best characteristic of the taro starch bio-plastic composite. This study used a factorial randomized block design. The first factor is the type of plasticizer which consists of 4 levels, namely glycerol, sorbitol, castor oil, and stearic acid. The second factor is the concentration of plasticizers with 4 levels, namely $0.5 \% ; 1 \% ; 1.5 \% ; 2 \%$. Each treatment was grouped into 2 based on the time of making bioplastics, so there were 32 experimental units. The variables observed were tensile strength, elongation at break, elasticity, thickness expansion, water vapor transmission rate, and biodegradation. The data obtained were analyzed for diversity and continued with the Honest Significant Difference test. The results showed that the type and concentration of plasticizers and their interactions had a very significant effect on tensile strength, elasticity, thickness expansion and water vapor transmission rate. The type of plasticizer and the concentration of the plasticizer have a very significant effect, while the interaction has no significant effect on elongation at break. The type of plasticizer and the concentration of the plasticizer and their interactions have no significant effect on biodegradation. The best characteristics of bio-plastic composites occurred when using stearic acid plasticizer with a concentration of $0.5 \%$ with a tensile strength value of $23.00 \mathrm{MPa}$, elongation at break $2.22 \%$, elasticity $1038.27 \mathrm{MPa}$, expansion 91.47\%, water vapor transmission rate $1.38 \mathrm{~g} / \mathrm{m} 2$. hour and 7 days of degradation. The bioplastics produced in this study have met the standards of SNI 7818:2014 on the variable tensile strength, elasticity and international standards ASTM 5336 on the variable length of degradation.
\end{abstract}

Key words: taro tuber starch, chitosan, composites bio-plastic, type and concentration of plasticizer.

\begin{abstract}
ABSTRAK
Penelitian ini bertujuan mengetahui pengaruh jenis dan konsentrasi pemlastis serta interaksinya terhadap karakteristik komposit bioplastik pati ubi talas serta menentukan jenis dan konsentrasi pemlastis yang menghasilkan komposit bioplastik pati ubi talas dengan karakteristik terbaik. Penelitian ini menggunakan Rancangan Acak Kelompok percobaan faktorial. Factor pertama jenis pemlastis yang terdiri dari 4 taraf, yaitu gliserol, sorbitol, minyak jarak, dan asam stearat. Factor kedua adalah konsentrasi pemlastis dengan 4 taraf, yaitu $0,5 \% ; 1 \% ; 1,5 \% ; 2 \%$. Masing-masing perlakuan dikelompokkan menjadi 2 berdasarkan waktu pembuatan bioplastik, sehingga terdapat 32 unit percobaan. Variabel yang diamati yaitu kuat tarik,
\end{abstract}

*Korespondensi Penulis:

Email: amnahartiati@unud.ac.id 
perpanjangan saat putus, elastisitas, pengembangan tebal, laju transmisi uap air, dan biodegradasi. Data yang diperoleh dianalisis keragamannya dan dilanjutkan dengan uji Beda Nyata Jujur. Hasil penelitian menunjukkan bahwa jenis dan konsentrasi bahan pemlastis serta interaksinya berpengaruh sangat nyata terhadap kuat tarik, elastisitas, pengembangan tebal dan laju transmisi uap air. Jenis bahan pemlastis dan konsentrasi bahan pemlastis berpengaruh sangat nyata sedangkan interaksinya tidak berpengaruh nyata terhadap perpanjangan saat putus. Jenis bahan pemlastis dan konsentrasi bahan pemlastis serta interaksinya tidak berpengaruh nyata terhadap biodegradasi. Karakteristik komposit bioplastik terbaik terjadi ketika menggunakan jenis pemlastis asam stearate dengan konsentrasi 0,5\% dengan nilai kuat tarik 23,00 MPa, perpanjangan saat putus 2,22\%, elastisitas 1038,27 MPa, pengembangan 91,47\%, laju transmisi uap air 1,383 g/m².jam dan lama degradasi 7 hari. Komposit bioplastik yang dihasilkan dalam penelitian ini telah memenuhi standar SNI 7818:2014 pada variabel kuat tarik, elastisitas dan standar internasional ASTM 5336 pada variabel lama degradasi.

Kata kunci: Pati ubi talas Belitung, kitosan, komposit bioplastik, jenis dan konsentrasi pemlastis.

\section{PENDAHULUAN}

Bioplastik merupakan plastik yang terbuat dari bahan-bahan alami yang dapat diurai oleh mikroorganisme, dibandingkan dengan plastik komersial bioplastik lebih ramah lingkungan. Bahan yang umum digunakan untuk bioplastik sintetik adalah pati dan kitosan (Agustin dan Padmawijaya, 2016). Pati merupakan bahan baku yang banyak digunakan di Indonesia. Pati diperoleh dengan mengekstraksi komponen nabati yang mengandung karbohidrat, seperti biji-bijian dan berbagai umbi. Sumber karbohidrat yang banyak mengandung pati di antaranya jagung, sagu, ubi kayu, beras, ubi jalar, sorgum, talas, dan garut. Sifat fungsional yang unik dari pati memungkinkan pati digunakan baik sebagai bahan pangan maupun non pangan (Koswara, 2009). Bioplastik berbasis pati adalah jenis bioplastik yang paling banyak diproduksi di Negara Eropa, Australia, dan Indonesia (Swamy dan Singh, 2010) karena pati memiliki sifat yang mudah terdegradasi, keberadaanya melimpah di alam, terjangkau, mudah diperoleh, murah (Aripin et al., 2017) dan menurut (Supeni et al., 2015) sifat pati juga sangat sesuai untuk bioplastik atau film karena dapat membentuk film yang kuat.

Salah satu sumber pati di Indonesia yang potensial untuk dijadikan bahan pembuatan bioplastik adalah pati umbi talas (Xanthosoma sagittifolium), karena menurut
(Ridal, 2003) kandungan pati di dalam talas $70-80 \%$. Kandungan pati yang terdapat pada umbi talas tersebut dapat digunakan sebagai bioplastik. Namun, bioplastik yang hanya berbahan baku dari pati memiliki kelemahan, yaitu rendahnya resistansi terhadap air dan juga rendahnya permeabilitas terhadap uap air dan sifat mekanisnya masih rendah (Garcia et al., 2011). Menurut Hilwatullisan dan Hamid (2019) untuk memperbaiki karakteristik fisik dan fungsional bioplastik pati, perlu dilakukan penambahan komposit dan pemlastis lain.

Kitosan merupakan bahan yang sering digunakan dalam sintesis bioplastik selain pati, kitosan adalah biopolymer sebagai bahan anti mikroba dan berfungsi sebagai penguat (Agustin dan Padmawijaya, 2016). Pemlastis merupakan bahan tambahan yang dapat meningkatkan fleksibelitas, menurut Darder et al., (2008) biasanya pemlastis ditambahkan kedalam cairan yang keras atau kaku, hal ini dapat membuat akumulasi gaya intermolekuler pada rantai Panjang akan menurun, akibatnya kelenturan, pelunakan dan pemanjangan bioplastik akan bertambah. Pada penelitian Dewi et al., (2015) menunjukkan bahwa hasil komposit bioplastik pada campuran $3 \mathrm{~g}$ pati dan $2 \mathrm{~g}$ kitosan belum memenuhi Standart SNI. Menurut (Hartatik et al., 2014) ada beberapa faktor yang mempengaruhi keberhasilan pembuatan bioplastik diantaranya jenis pemlastis, konsentrasi bahan pemlastis, 
bahan tambahan dan konsentrasi pati. Katili et al., (2013) juga menyarankan agar melakukan variasi jenis dan konsentrasi pemlastis pada pembuatan komposit bioplastik yang berbahan dasar pati dan kitosan.

Pada penelitian Nurfajrin et al., (2019) dalam pembuatan edible film dari pati kulit pisang nangka dan kitosan menghasilkan karakteristik terbaik dengan menggunakan $5 \mathrm{ml}$ pemlastis gliserol, kuat tarik sebesar 4,26 MPa, dan elongasi sebesar 14\%. Penelitian selanjutnya dilakukan oleh Putra et al., (2017) dalam pembuatan edible film pati sukun, didapatkan hasil terbaik menggunakan sorbitol $0,4 \%$ dengan nilai kuat tarik 10,33 $\mathrm{MPa}$, elongasi sebesar $5,29 \%$, dan laju transmisi uap air sebesar $462,11 \mathrm{~g} / \mathrm{m}^{2} / 24 \mathrm{jam}$. Penelitian lain yang dilakukan oleh Hillan (2016) menunjukkan hasil terbaik bioplastik dengan kitosan dan pati singkong menggunakan $4 \%$ pemlastis asam stearat dengan nilai kuat tarik sebesar 20 Mpa, persen pemanjangan 9,47\%. Gunawan Fajri (2017) juga melakukan penelitian pembuatan bioplastik dari pati talas dan kitosan dengan perlakuan terbaik menggunakan minyak jarak $15 \%$ yang menghasilkan kuat tarik 11,740 Mpa.

Dari keempat penelitian diatas menjelaskan bahwa jenis bahan dan konsentrasi pemlastis belum tepat karena belum menghasilkan bioplastik yang sesuai standar SNI. Menurut Gunawan Fajri (2017), hal tersebut dikarenakan konsentrasi yang digunakan pada penelitian terlalu tinggi dan tidak sesuai dengan konsentrasi bahan baku yang digunakan. Jenis pemlastis dan konsentrasi pemlastis dapat mempengaruhi sifat film, jika penambahan dengan jenis dan konsentrasi pemlastis yang salah akan mempengaruhi karakteristik bioplastik yang dihasilkan utamanya pada karakteristik mekanik dan fisik Cuq et al., (1996). Penambahan pemlastis yang tepat akan mengurangi kerapuhan, meningkatkan fleksibilitas serta ketahanan film. Oleh karena itu, pada penelitian ini dilakukan penelitian dengan memperlakukan jenis pemlastis dan konsentrasi pemlastis yang tepat dalam pembuatan komposit bioplastik pati ubi talaskitosan.

Tujuan dari penelitian ini adalah untuk mengetahui pengaruh jenis dan konsentrasi pemlastis serta interaksi keduanya terhadap karakteristik komposit bioplastik pati talas-kitosan serta untuk memperoleh jenis dan konsentrasi pemlastis yang tepat untuk menghasilkan komposit bioplastik pati talas-kitosan dengan karakteristik terbaik.

\section{METODE PENELITIAN}

\section{Tempat dan Waktu Penelitian}

Pembuatan pati, komposit bioplastik, uji penyerapan air, dan uji WVTR dilakukan di Laboratorium Biokimia dan Nutrisi Fakultas Teknologi Pertanian, Universitas Udayana. Uji kuat tarik, elongasi dan elastisitas dilakukan di Fakultas Teknologi Pertanian, Universitas Brawijaya. Uji biodegradasi dilakukan di Green House Fakultas Teknologi Pertanian, Universitas Udayana. Penelitian ini dilakukan pada bulan Maret sampai April 2021.

\section{Alat dan Bahan}

Alat yang digunakan untuk melakukan penelitian ini, yaitu timbangan analitik (PIONEER ${ }^{\mathrm{TM}}$ ), cetakan (teflon Maxim Valentino $20 \mathrm{~cm}$ ), blender (Miyako CH-511 PLY), sendok teh, sendok makan, pengaduk, hot plate (JP. SELECTA), thermometer, gelas ukur $100 \mathrm{ml}$ (IWAKICTE33), pipet tetes (pipet tetes plastic $3 \mathrm{ml}$ ), beaker glass (IWAKITG32 PYREX), talenan, penggaris, baskom, cutter, kain saring, pisau, gunting, dan oven, serta peralatan uji kadar air, alat uji WVTR, alat uji mekanik plastic berdasarkan ASTM D638.

Bahan yang digunakan untuk penelitian ini adalah pati ubi talas belitung 
(Xanthosoma sagittifolium) yang dibei dari pasar Ampera Jimbaran, kitosan dari CV. Nura Jaya, silica gel, pemlastis gliserol, sorbitol, asam stearat, minyak jarak, dan aquades dari UD. Saba Kimia, Denpasar Utara.

\section{Rancangan Percobaan}

Penelitian ini mengunakan Rancangan Acak Kelompok (RAK) percobaan factorial dengan 2 faktor. Faktor pertama adalah jenis pemlastis yang terdiri dari empat taraf, yaitu gliserol, sorbitol, minyak jarak, dan Asam stearat. Faktor kedua adalah konsentrasi pemlastis yang terdiri dari empat taraf yaitu: $(0,5 \% ; 1 \% ; 1,5 \% ; 2 \%)$. Masing-masing perlakuan dikelompokkan menjadi 2 beradasarkan waktu pembuatan bioplastik, sehingga terdapat 32 unit percobaan. Data yang diperoleh dianalisis keragamannya (ANOVA) dan dilanjutkan dengan uji BNJ. Pengolahan data dilakukan menggunakan perangkat lunak Minitab 19.

\section{Pelaksanaan Penelitian \\ Proses pembuatan komposit bioplastik}

Melakukan penimbangan pati ubi talas:kitosan sebanyak $5 \mathrm{gr} \quad(3 \mathrm{~g}: 2 \mathrm{~g})$ berdasarkan Dewi et al., (2015) dan mengukur larutan asam cuka $1 \%$ dengan total $100 \mathrm{ml}$, kemudian membagi larutan asam cuka $1 \%$ menjadi dua bagian yang selanjutnya dimasukkan ke dalam 2 beaker glass yang berbeda. Kitosan dimasukan ke dalam beaker glass 1 dilarutkan terlebih dahulu dengan pengadukan selama 10 menit dengan suhu $80^{\circ} \mathrm{C}$, dan yang kedua pelarutan pati talas dimasukan kedalam beaker glass 2 dengan pengadukan selama 5 menit pada suhu $70^{\circ} \mathrm{C}$. Setelah kedua larutan tersebut larut dicampur kedalam beaker glass. Campuran pati dan kitosan tersebut kemudian ditambahkan pemlastis dengan perlakuan yang berbeda $(0,5 \%, 1 \%, 1,5 \%$ dan $2 \%)$ dengan pencampuran, pengadukan, dan pemanasan pada suhu $80^{\circ} \mathrm{C}$ selama 10 menit, sampai berbentuk gel. Gel komposit pati- kitosan yang dihasilkan dituang ke dalam cetakan Teflon dengan diameter $20 \mathrm{~cm}$. Selanjutnya dimasukkan pada oven pengering pada suhu $50{ }^{\circ} \mathrm{C}$ selama \pm 24 jam. Lapisan plastik yang terbentuk dikeluarkan dari oven dan didinginkan di suhu ruang selama 24 jam. Selanjutnya bioplastik diambil dari Teflon dan siap untuk diuji sesuai variable yang diamati (Modifikasi Dewi et al., 2015).

\section{Variabel yang diamati}

Variabel yang diukur kekuatan tarik (tensile strength) (SNI 7818: 2014), perpanjangan (elongation at break) (SNI 7818: 2014) dan Modulus young (elastisitas) (SNI 7818: 2014), kemampuan biodegradasi (ASTM 5336), Water Vapour Transmission Rate (WVTR) (Japan International Standart 2-1707), dan Uji pengembangan tebal (Swelling) (EN317).

\section{HASIL DAN PEMBAHASAN}

\section{Hasil Bioplastik}

Hasil komposit bioplastik yang diperoleh dari penelitian ini berupa lembaran bening seperti yang terlihat pada Gambar 1 .

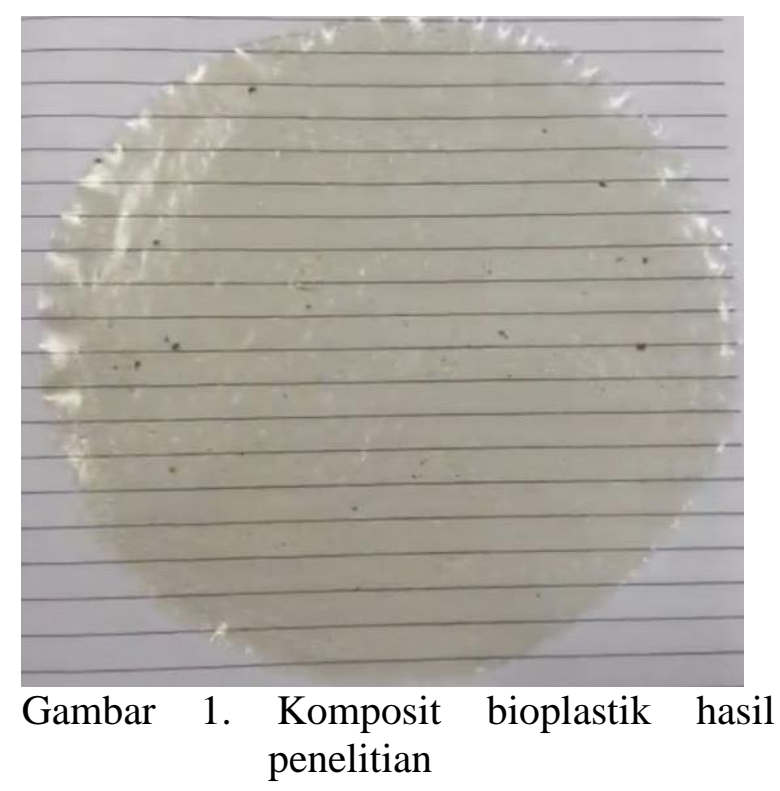

Kuat Tarik (tensile strength) 
Berdasarkan hasil analisis keragaman menunjukkan bahwa jenis bahan pemlastis dan konsentrasi bahan pemlastis serta interaksinya berpengaruh sangat nyata ( $<<0,01)$ terhadap kuat tarik bioplastik yang dihasilkan. Nilai kuat tarik bioplastik komposit pati ubi talas belitung (Xanthosoma sagittifolium)-kitosan, yang dihasilkan berkisar 2,505 - 23,00 MPa yang dapat dilihat pada Gambar 2.

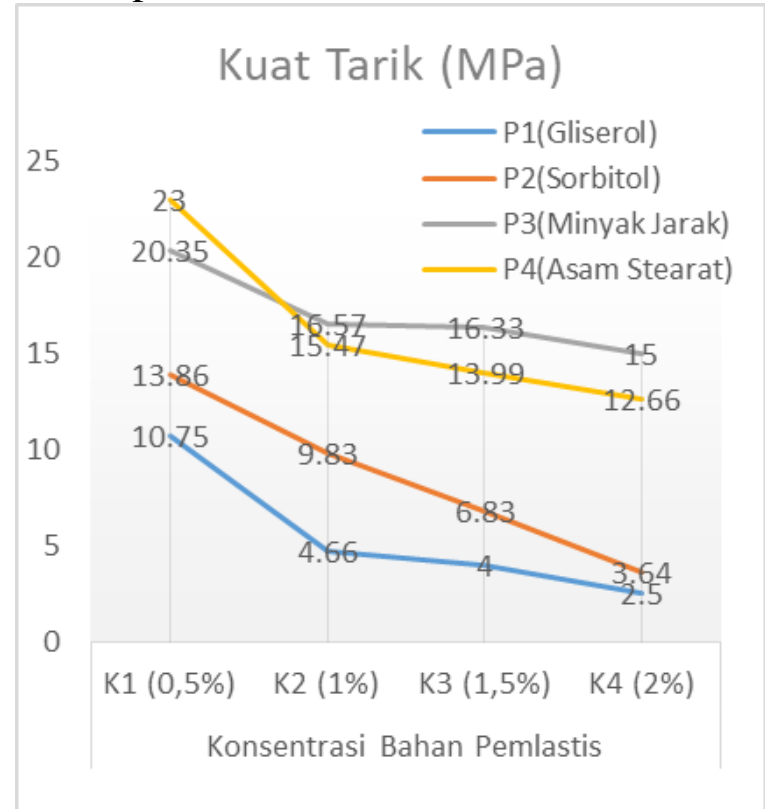

Gambar 2. Nilai rata-rata kuat tarik (MPa) komposit bioplastic pati ubi talas Belitung(Xanthosoma sagittifolium)-kitosan

Uji ini berguna untuk mengetahui besar gaya yang diraih pada tarikan maksimum terhadap satuan luas area film untuk merenggang atau memanjang (Krochta dan Mulder-Johnston,1997). Gambar 2 menunjukkan bahwa komposit bioplastik pati ubi talas - kitosan yang menggunakan $0,5 \%$ minyak jarak maupun $0,5 \%$ asam stearat menghasilkan kuat tarik yang tinggi dengan nilai masing-masing 20,35 $\mathrm{MPa}$ dan 23,00 $\mathrm{MPa}$ yang berbeda nyata dengan lainnya. Sementara itu, komposit bioplastik pati ubi talas-kitosan yang menggunakan $2 \%$ gliserol menghasilkan kuat tarik terendah (2,505 $\mathrm{MPa}$ ) yang tidak berbeda nyata dengan komposit bioplastik yang menggunakan $1 \%$ dan 1,5\% gliserol dan 2\% sorbitol. Yang dan Poulson (2000) mengatakan bahwa interaksi bahan pemlastis dan polimer dipengaruhi oleh ukuran molekul dan jumlah gugus fungsional hidroksil bahan pemlastis serta kompabilitas dengan polimernya.

Gambar 2 menunjukkan semakin banyak konsentrasi pemlastis yang ditambahkan maka nilai kuat tariknya akan semakin menurun, (Katili et al .,2013) menyatakan hal yang serupa semakin banyak pemlastis yang ditambahkan ke dalam pembuatan bioplastik maka nilai kekuatan tarik akan semakin berkurang. Menurut (Purwanti, 2010) hal ini dikarenakan penambahan konsentrasi pemlastis dapat menyebabkan molekul pada pemlastis tersebut terletak diantara rantai ikatan biopolymer dan berinteraksi membentuk ikatan hydrogen dalam rantai ikatan antar polimer tersebut, oleh sebab itu interaksi antar biopolymer semakin berkurang.

Berdasarkan Standar Nasional Indonesia (SNI) 7818:2014 plastik harus memiliki nilai kuat tarik minimal 13,7 MPa, dari hasil penelitian ini nilai kuat tarik yang dihasilkan komposit pati ubi talas belitung (Xanthosoma sagittifolium)-kitosan adalah 2,505 MPa - 23,000 MPa yang berarti sudah ada beberapa bioplastik yang memenuhi standar nilai dari SNI 7818:2014 plastik.

\section{Perpanjangan Saat Putus (elongation at break)}

Berdasarkan hasil analisis keragaman menunjukkan bahwa jenis bahan pemlastis dan konsentrasi bahan pemlastis berpengaruh sangat nyata $(\mathrm{p}<0,01)$ sedangkan interaksinya tidak berpengaruh nyata terhadap perpanjangan saat putus bioplastik yang dihasilkan. Nilai perpanjangan saat putus bioplastik komposit pati ubi talas belitung (Xanthosoma sagittifolium)-kitosan yang dihasilkan berkisar 2,215-8,750 \% dapat dilihat pada Gambar 3. 


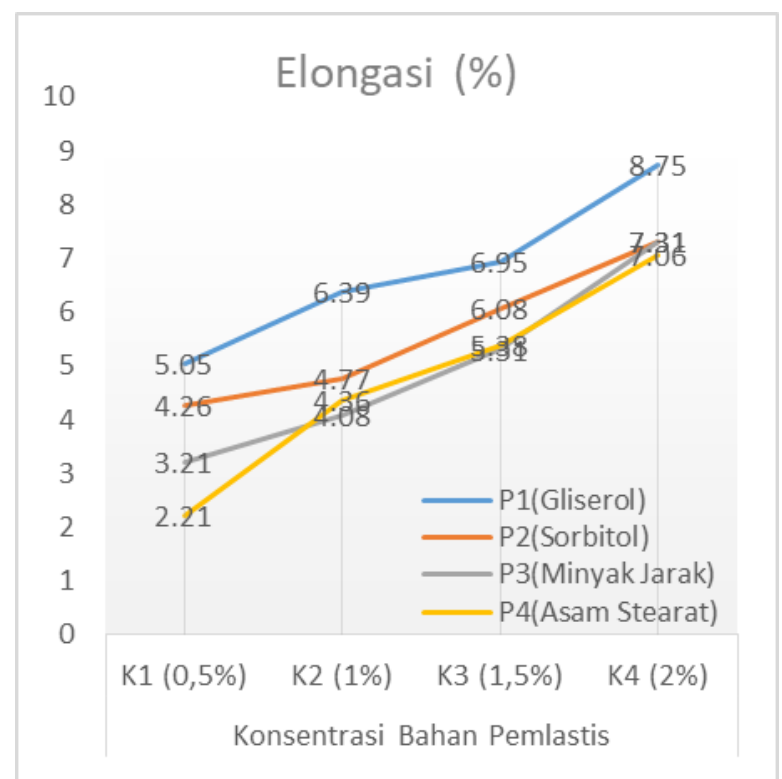

Gambar 3. Nilai rata-rata elongasi (\%) komposit bioplastik pati ubi talas belitung (Xanthosoma sagittifolium)-kitosan

Persen Perpanjangan saat putus merupakan persentasi perubahan elongasi maksimal suatu edible film pada saat edible film tersebut ditarik sampai putus (Krochta, 1994). Gambar 3 menunjukkan bahwa komposit bioplastik pati ubi talas - kitosan dengan nilai perpanjangan saat putus tertinggi pada penelitian ini ialah $8,750 \%$ menggunakan bahan pemlastis gliserol dengan konsentrasi $2 \%$ yang tidak berbeda nyata dengan gliserol $1,5 \%$ sorbitol $2 \%$, dan minyak jarak 2\%. Sedangkan nilai perpanjangan saat putus komposit bioplastik ubi talas-kitosan terendah yaitu 2,215\% berbahan pemlastis asam stearat dengan konsentrasi $0,5 \%$ yang tidak berbeda nyata dengan minyak jarak $0,5 \%$. Nilai perpanjangan saat putus berbanding terbalik dengan nilai kuat tarik, hal ini dapat dilihat pada pengunaan pemlastis minyak jarak $0,5 \%$ memiliki nilai rata-rata kuat tarik tertinggi sedangkan nilai rata-rata perpanjangan saat putus terendah dan sebaliknya pada penggunaan gliserol $2 \%$ memiliki nilai ratarata kuat tarik terendah dan nilai rata-rata perpanjangan putus tertinggi.

Gambar 3 menunjukkan bahwa semakin banyak konsentrasi pemlastis yang ditambahkan nilai perpanjangan saat putuspun semakin tinggi hal ini di dukung oleh Putra et al., (2017) yang menjelaskan semakin tinggi konsentrasi pemlastis yang ditambahkan maka energi aktivasi untuk bergeraknya molekul dalam matriks terganggu (semakin mengecil atau berkurang) hal tersebut yang menyebabkan nilai elastisitas dari edible film bertambah sehingga perpanjangan saat putus akan meningkat, dan menurut Ratnaningtyas, (2019) penambahan konsentrasi pemlastis akan menyebabkan kemampuan molekul pada bioplastik untuk saling berikatan akan menurun.

Hasil penelitian menunjukkan nilai rata-rata perpanjangan saat putus masih belum memenuhi SNI, jika berdasarkan Standar Nasional Indonesia (SNI) 78188.7:2014 plastik harus memiliki nilai perpanjangan saat putus 21-220\%. Sedangkan nilai perpanjangan saat putus dari komposit pati ubi talas belitung (Xanthosoma sagittifolium)-kitosan pada penelitian ini adalah 2,215-8,750\% yang berarti bioplastik belum memenuhi standar nilai dari SNI 7818.7:2014.

\section{Elastisitas (modulus young)}

Berdasarkan hasil analisis keragaman menunjukkan pada bioplastik komposit pati ubi talas belitung (Xanthosoma sagittifolium)-kitosan, bahwa jenis bahan pemlastis dan konsentrasi bahan pemlastis serta interaksinya berpengaruh sangat nyata $(\mathrm{p}<0,01)$ terhadap elastisitas bioplastik yang dihasilkan. Nilai elastisitas bioplastik komposit pati ubi talas belitung (Xanthosoma sagittifolium)-kitosan yang dihasilkan berkisar 43,55 - 1038,27 MPa dapat dilihat pada Gambar 4.

Gambar 4 menunjukkan bahwa komposit bioplastik pati ubi talas-kitosan memiliki nilai elastisitas tertinggi, yaitu 
1038,27 MPa menggunakan asam stearat dengan konsentrasi $0,5 \%$ yang berbeda nyata dengan lainnya. Sementara itu komposit bioplastik pati ubi talas-kitosan dengan nilai elastisitas terendah ialah gliserol 2\%, 1,5\%, $1 \%$ dan sorbitol $2 \%$ yang tidak berbeda nyata dengan gliserol $0,5 \%$ sorbitol $1 \%, 1,5 \%$, minyak jarak $2 \%$ dan asam stearat $2 \%$. Menurut (Darni dan Utami, 2010) nilai elsatisitas yang dihasilkan pada bioplastik berbanding lurus dengan nilai kuat tarik dan berbanding terbalik dengan nilai perpanjangan saat putusnya, hal tersebut bisa dilihat pada asam stearat $0,5 \%$ memiliki nilai rata-rata kuat tarik dan elastisitas tertinggi namun nilai perpanjangan saat putus yang terendah.

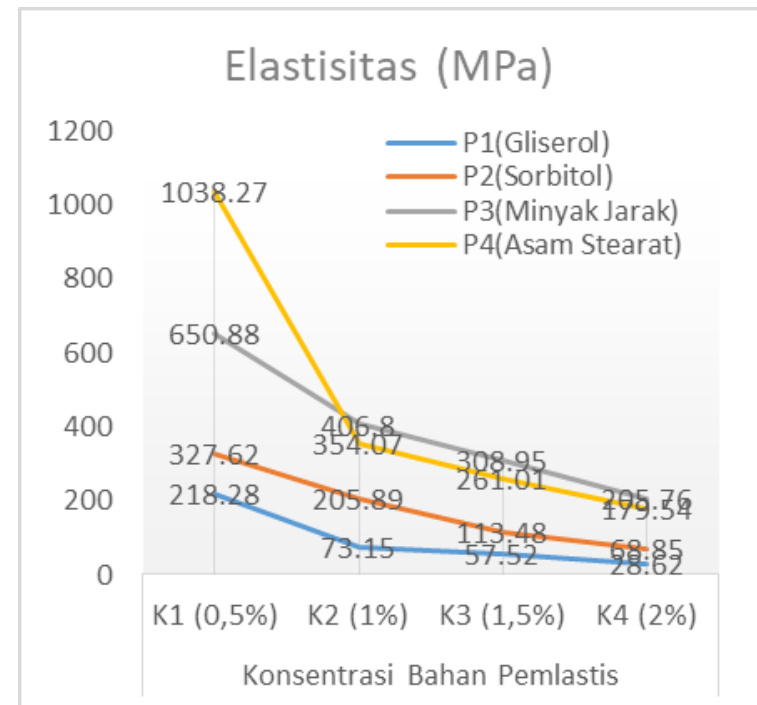

Gambar 4. Nilai rata-rata elastisitas (MPa) komposit bioplastik pati ubi talas belitung (Xanthosoma sagittifolium)-kitosan

Menurut (Coniwati et al., 2014) menurunnya nilai elastisitas terjadi karena sudah terlampauinya titik jenuh, hal tersebut menyebabkan molekul bahan pemlastis yang berlebihan berada pada fase tersendiri diluar fase polimer dan akan menurunkan gaya intermolekul antar rantai yang menyebabkan gerakan pada rantai lebih bebas.

Berdasarkan SNI 7818:2014 plastik harus memiliki nilai elastisitas minimal 40-
$1120 \mathrm{MPa}$. Nilai elastisitas dari komposit pati ubi talas belitung (Xanthosoma sagittifolium)-kitosan pada penelitian ini adalah 43,55 - 1038,27 MPa yang berarti bioplastik sudah memenuhi standar nilai dari SNI 7818:2014.

\section{Pengembangan (Swelling)}

Berdasarkan hasil analisis keragaman menunjukkan bahwa jenis bahan pemlastis dan konsentrasi bahan pemlastis serta interaksinya berpengaruh sangat nyata $(p<0,01)$ terhadap elastisitas bioplastik yang dihasilkan. Nilai swelling bioplastik komposit pati ubi talas belitung (Xanthosoma sagittifolium)-kitosan yang dihasilkan berkisar 66,675 - 91,465\% dapat dilihat pada Gambar 5.

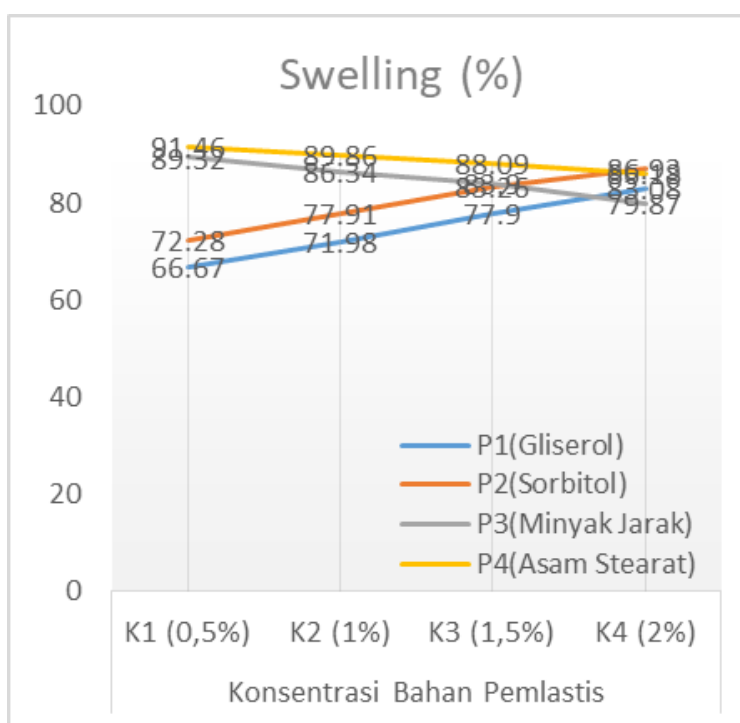

Gambar 5. Nilai rata-rata penyerapan air (\%) komposit bioplastik pati ubi talas belitung (Xanthosoma sagittifolium)-kitosan

Dari Gambar 5 dapat dilihat nilai swelling komposit bioplastik pati ubi talaskitosan tertinggi pada penambahan pemlastis asam stearat dengan konsentrasi $0,5 \%$ sebesar $91,465 \%$ yang tidak berbeda nyata dengan asam stearat $1 \%$ dan minyak jarak $0,5 \%$ sementara itu nilai swelling komposit bioplastik pati ubi talas-kitosan terendah sebesar $66,675 \%$ dengan penambahan 
pemlastis gliserol 0,5\%. Hal ini terjadi karena jenis pemlastis dan penambahan konsentrasi pemlastis berpengaruh pada penyerapan air bioplastik, Goldberg dan Williams (1991) mengatakan bahwa perbedaan berat molekul pada pemlastis akan menyebabkan perbedaan penyerapan air pada bioplastik tersebut. Nilai swelling dengan penambahan asam Stearat dan minyak jarak mengalami penurunan dikarenakan asam stearat dan minyak jarak merupakan jenis pemlastis hidrofobik, oleh sebab itu semakin besar konsentrasi asam stearat dan minyak jarak yang ditambahkan maka presentasi swelling akan semakin kecil. Sedangkan pada penambahan gliserol dan sorbitol mengalami peningkatan nilai swelling seiring dengan peningkatan konsentrasinya hal ini dikarenakan gliserol dan sorbitol memiliki sifat hidrofilik, mampu mengikat air yang lebih besar, dan menurut (Agustin dan Padmawijaya, 2016) gliserol dan sorbitol bersifat higrokopis dan memiliki gugus - $\mathrm{OH}$ yang banyak dan dapat berikatan dengan air melalui interaksi hydrogen dan memiliki nilai daya serap air yang tinggi.

Berdasarkan Standart International (EN 317) besarnya nilai swelling 1,44\%. Besarnya nilai swelling yang dihasilkan pada penelitian ini belum memenuhi standar plastic internasional.

\section{Uji Water Vapour Transmission Rate (WVTR)}

Berdasarkan hasil analisis keragaman menunjukkan bahwa jenis bahan pemlastis dan konsentrasi bahan pemlastis serta interaksinya berpengaruh sangat nyata $(\mathrm{p}<0,01)$ terhadap WVTR bioplastik yang dihasilkan. Nilai WVTR bioplastik komposit pati ubi talas belitung (Xanthosoma sagittifolium)-kitosan yang dihasilkan berkisar $0,336-1,383 \mathrm{~g} / \mathrm{m}^{2}$.jam dapat dilihat pada Gambar 6.

WVTR digunakan untuk mengetahui nilai permeabilitas suatu bahan terhadap uap air. Permeabilitas uap air merupakan ukuran suatu bahan dapat dilalui, ditebus, atau diserapi oleh uap air (Krochta, 1997).

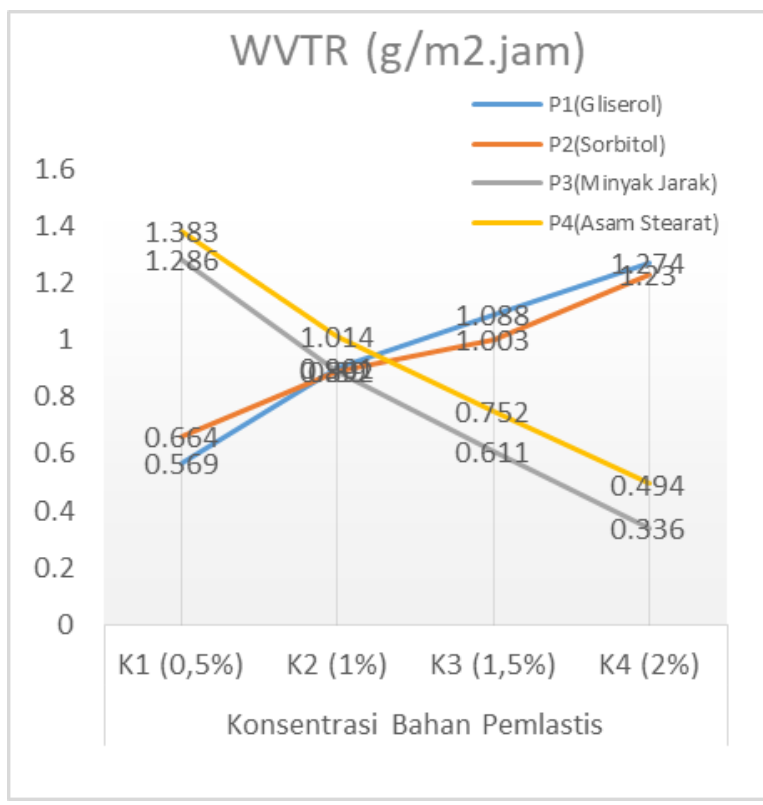

Gambar 6. Nilai rata-rata Water Vapour Transmission Rate (\%) komposit bioplastik pati ubi talas belitung (Xanthosoma sagittifolium)-kitosan.

Berdasarkan Gambar 6 dapat dilihat bahwa nilai laju transmisi uap air komposit bioplastik pati ubi talas-kitosan terendah terdapat pada penambahan minyak jarak $2 \%$ sebesar $0,336 \mathrm{~g} / \mathrm{m}^{2} / \mathrm{jam}$ yang tidak berbeda nyata dengan gliserol $0,5 \%$ dan asam stearat $2 \%$. Nilai laju transmisi uap air komposit bioplastik ubi talas-kitosan tertinggi terdapat pada bioplastik dengan penambahan asam stearat $0,5 \%$, yaitu sebesar $1,383 \mathrm{~g} / \mathrm{m}^{2}$.jam yang tidak berbeda nyata dengan minyak jarak $0,5 \%$. Hal ini dikarenakan jenis dan konsentrasi pemlastis sangat mempengaruhi nilai transmisi uap air (Katili dan Irawan, 2013) selain itu (Anandito dan Bukhori, 2012) menyebutkan bahwa migrasi uap air terjadi pada film yang mengandung pemlastis hidrofilik, semakin besar konsentrasi hidrofilik pada film akan menyebabkan nilai laju transmisi uap air tersebut semakin meningkat, sebaliknya semakin besar konsentrasi hidrofobik pada film dapat menyebabkan nilai laju transmisi uap air 
tersebut semakin turun.

Berdasarkan Japan International Standart (JIS) 2-1707 minimal nilai laju transmisi uap air (WVTR) ialah 0,0292. Nilai laju transmisi uap air yang dihasilkan pada penelitian ini berkisar 0,336-1,383 g/m².jam yang berarti belum memenuhi standar plastic internasional.

\section{Biodegradasi}

Berdasarkan hasil analisis keragaman menunjukkan bahwa jenis bahan pemlastis dan konsentrasi bahan pemlastis serta interaksinya tidak berpengaruh nyata (p>0,05) terhadap biodegradasi bioplastik yang dihasilkan. Waktu biodegradasi bioplastik komposit pati ubi talas belitung (Xanthosoma sagittifolium)-kitosan yang dihasilkan berkisar $7-8$ hari. Nilai laju biodegradasi bioplastik dapat dilihat pada Gambar 7.

Uji biodegradasi dilakukan dengan menimbun bioplastik di dalam tanah selama beberapa hari (Subowo, 2003). Biodegradasi memiliki tujuan untuk mengetahui seberapa lama waktu yang dibutuhkan suatu bioplastik untuk dapat terurai di dalam lingkungan. Dari Gambar 7 dapat dilihat bahwa kemampuan biodegradasi dari bioplastik pati ubi talas belitung (Xanthosoma sagittifolium)-kitosan tidak ada perbedaan pada setiap perlakuan, hal ini karena menurut (Hidayati et al., 2015) kecepatan biodegradasi tergantung pada temperature, kelembapan dan tipe mikroba, dan didukung juga oleh (Darni dan Utami, 2010) yang menyatakan bahwa bioplastik yang dihasilkan mengandung $\mathrm{OH}$ atau gugus hidroksil dan $\mathrm{CO}$ atau gugus karbonil. Kedua gugus tersebut bersifat hidrofilik yang mengakibatkan molekul air mendukung mikroorganisme pada lingkungan memasuki matriks plastik tersebut.

(Xanthosoma sagittifolium)-kitosan dapat terdegradasi dalam waktu 7-8 hari karena bioplastik tersebut terbuat dari pati yang menyebabkan mudah terdegradasi di alam dengan bantuan mikroorganisme didalam tanah. Berdasarkan Standart Internasional (SI) menurut maksimal bioplastik terdegradasi di alam 60 hari. Pada penelitian ini lamanya waktu bioplastik terdegradasi adalah 7-8 hari, hal ini berarti kemampuan degradasi bioplastik tersebut sudah dapat memenuhi Standart Internasional (SI).

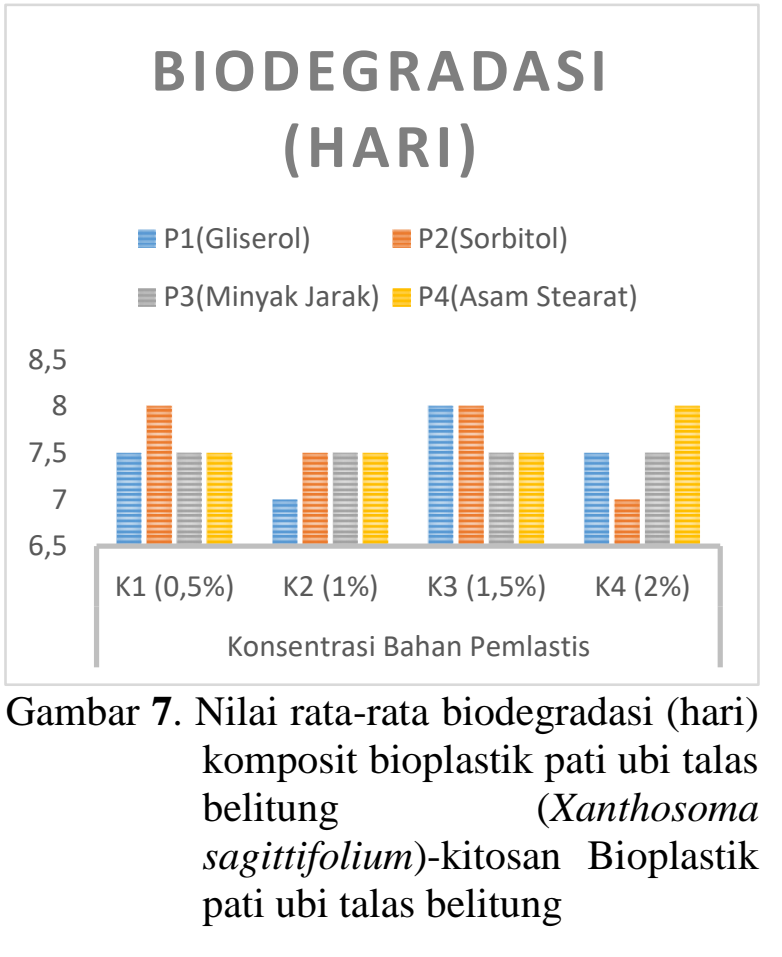

\section{KESIMPULAN DAN SARAN}

\section{Kesimpulan}

Berdasarkan penelitian yang telah dilakukan maka dapat disimpulkan bahwa:

1) Jenis dan konsentrasi pemlastis berpengaruh sangat nyata terhadap kuat tarik, perpanjangan saat putus, elastisitas, pengembangan, dan laju transmisi uap air. Sementara itu jenis dan konsentrasi pemlastis tidak berpengaruh nyata terhadap lama biodegradasi. Interaksinya berpengaruh sangat nyata terhadap kuat tarik, elastisitas, pengembangan, dan WVTR serta tidak berpengaruh nyata terhadap perpanjangan saat putus dan lama biodegradasi. 
2) Komposit bioplastik pati talas Belitung terbaik didapatkan pada perlakuan jenis bahan pemlastis asam stearat dengan konsentrasi $0,5 \%$ yang menghasilkan kuat tarik sebesar 23,00 $\mathrm{MPa}$, perpanjangan saat putus 2,215\%, elastisitas 1038,27 $\mathrm{MPa}$, pengembangan tebal $91,465 \%$, laju transmisi uap air $1,383 \mathrm{~g} / \mathrm{m}^{2} . j a m$, dan terdegradasi dalam 7 hari. Bioplastik yang dihasilkan dalam penelitian ini telah memenuhi standar SNI 7818:2014 pada variable uji kuat tarik, variable uji elastisitas, dan standar international ASTM 5336 pada variable lama degradasi. Bioplastik yang dihasilkan belum memenuhi Standar internasional plastic pada variable uji swelling dan uji WVTR

\section{Saran}

Perlu dilakukan penelitian lebih lanjut dalam mengembangkan dan meningkatkan lama pengadukan, dan penambahan filler yang bersifat hidrofobik untuk memperbaiki nilai swelling dan WVTR komposit bioplastik pati talas belitung.

\section{DAFTAR PUSTAKA}

Agustin, Y. E. dan K. S. Padmawijaya. 2016. Sintesis bioplastik dari kitosan-pati kulit pisang kepok dengan penambahan zat aditif. Jurnal Teknik Kimia. 10(2): 2-16.

Anandito, R. B. K dan A. Bukhori. 2012. Pengaruh gliserol terhadap karakteristik edible film berbahan dasar tepung jail (Coix Lacryma-Jobi L). Jurnal Teknologi Hasil Pertanian. 5(1): 17-23.

Darder, M., P. Arandar, I.A. Ruiz, M.F. Fernandes and H.E. Ruiz. 2008. Design and preparation of bionanocomposites based on layered solids with functional and structural properties. Material Science and Technology. 24(9): 1100-
1110.

Darni, Y dan H. Utami. 2010. Studi pembuatan dan karakteristik sifat mekanik dan hidrofobisitas bioplastik dari pati sorgum. Jurnal Rekayasa Kimia dan Lingkungan. 7(4): 88-93.

Dewi, G. A. A. M. P., B. A. Harsojuwono, dan I. W. Arnata. (2015). Pengaruh campuran bahan komposit dan konsentrasi gliserol terhadap karakteristik bioplastik dari pati kulit singkong dan kitosan. Jurnal Rekayasa dan Manajemen Agroindustri, 3(3), 4150.

Coniwati, P. L. Laila dan M.R. Alfira. 2014. Pembuatan film plastic biodegradable dari pati jagung dengan penmabahan kitosan dan pemlastis gliserol. Jurnal Teknik Kimia. 20(4): 22-30

Garcia, N.L., L. Ribbon, A. Dufresne, M. Aranguren, and S. Goyanes. 2011. Effect of glycerol on the morphology of nanocomposites made from thermoplastic strach and strach nanocrystals. Carbohydrate Polymers. 84(1): 203-210.

Fajri, G. 2017. Pembuatan dan karakteristik bioplastik dari kitosan, pati talas (colocasia esculenta) dan minyak jarak. Skripsi. Tidak dipublikasikan. Fakultas Keguruan dan Ilmu Pendidikan Unsyiah, Banda Aceh.

Goldberg, I. and R. Williams. 1991. Biotechnology and Food Ingredients. A user's guide to the general health questionnaire. London: Nfer-Nelson.

Hartatik, Y. D., L. Nuriyah dan Iswarin. 2014. Pengaruh Komposisi Kitosan Terhadap Sifat Mekanik Dan Biodegradable Bioplastik. Skripsi. Tidak dipublikasikan. Universitas Brawijaya, Malang. 
Hidayati, S., A. S. Zuidar dan A. Ardiani. 2015. Aplikasi sorbitol pada produksi biodegradable film dari nata de cassava. Jurnal Teknologi Hasil Pertanian. 15(3): 196-204.

Hilwatullisan dan I. Hamid. 2019. Pengaruh kitosan dan plasticizer gliserol dalam pembuatan plastik biodegradable dari pati talas. Jurnal Prosiding Seminar Nasional II Hasil Litbangyasa Industri. 45(8).221-227.

Hillan, L.R., S. Wafiroh., dan Suryanto. 2016. Pembuatan dan karakterisasi bioplastik dari komposit kitosan-pati singkong-selulosa diasetat dari serat batang pisang kepok (Musa paradisiaca normalis) dengan plasticizer asam stearat. Jurnal MIPA. Vol 16 (1) : $42-52$.

Iriani, E. S., T. C Sunarti and N. Richana. 2011. Pengembangan Biodegradable Foam Berbahan Baku Pati: Badan Litbang Pertanian.

Katili, S., B. T. Harsunu dan S. Irawan. 2013. Pengaruh konsentrasi plasticizer gliserol dan komposisi khitosan dalam zat pelarut terhadap sifat fisik edible film dari khitosan. Jurnal Teknologi. 6(1): 29-38.

Koswara, S. 2009. Teknologi Modifikasi Pati. E-book Pangan.com. http://tekpan.unimus.ac.id/wpcontent/uploads/2013/07/TEKNOLOG I-MODIFIKASI-PATI.pdf. Diakses 28 Desember 2020.

Krochta J M and C. Mulder-Johnston. 1997. Edible and biodegradable polymer films: challenges and oppurtunities. $J$. Food Tech. 51 (2): 61-74.

Mahatmanti, F. W., W.Sugiyo dan W. Sunarto. 2010. Sintesis kitosan dan pemanfaatannya sebagai anti mikroba ikan segar. Jurnal Sains dan Teknologi.
8(2): 101-111.

Melani, A., N. Herawati dan A. F. Kurniawan. 2017. Bioplastik pati umbi talas melalui proses melt intercalation (Kajian pengaruh jenis filler, konsentrasi filler dan jenis plasticiezer). Jurnal Distilasi. 2(2): 5367.

Murdianto dan Wiwit. 2005. Sifat fisik dan mekanik edible film ekstrak daun janggelan (Mesona palustris). Jurnal Agrosains. 3 (18) :3-10.

Nurfajrin, Z. D., Mahendrajaya, S. Sukadarti, dan Sulistyowati, E. (2015). Karakterisasi dan sifat biodegradasi edible film dari pati kulit pisang nangka (Musa paradisiaca 1.) dengan penambahan kitosan dan plasticizer gliserol. Prosiding Seminar Nasional Teknik Kimia Kejuangan.

Putra, D. M. D. P., B. A. Harsojuwono dan A. Hartiati. 2019. Studi suhu dan $\mathrm{pH}$ gelatinisasi pada pembuatan bioplastik dari pati kulit singkong. Jurnal Rekayasa dan Manajemen Agroindustri. 7(3): 441-449.

Putra, A. D., V. S. Johan dan R. Efendi. 2017. Penambahan sorbitol sebagai plasticizer dalam pembuatan edible film pati sukun. JOM Fakultas Pertanian. 4(2): 1-15.

Purwanti, A. (2010). Analisis kuat tarik dan elongasi plastik kitosan terplastisasi sorbitol. Jurnal Teknologi,. 3(2): 99106.

Ridal, S. 2003. Karakteristik Sifat FisioKimia Tepung dan Pati Talas (Colocasia esculenta) dan Kimpul (Xanthosoma sp.) dan Uji Penerimaan amilase Terhadap Patinya. Skripsi. Tidak dipublikasi. IPB.

Supeni, G., A. A.Cahyaningtyas dan A. Fitrina. 2015. Karakteristik sifat fisik 
dan mekanik penambahan kitosan pada edible film karagen dan tapioka termodifikasi. Jurnal Kimia Kemasan. 37(2): 103-110.

Swamy, J.N. and B. Singh. 2010. Bioplastics and global sustainability. Plastics Research Online. Society of Plastics Engineers. 10.1002/spepro. 003219.

Yang, L., and A. T. Paulson. 2000. Effects lipids on mechanical and moisture barrier properties of edible gellan film. Food Res. Int. 33: 571-578. 